\title{
THE INFLUENCE OF BIOHYDROHUMUS ON GROWTH AND DEVELOPMENT OF GARDEN PANSY (Viola $x$ wittrockiana Gams.)
}

\author{
Piotr Żurawik, Monika Placek \\ Laboratory of Ornamental Plants in the Department of Horticulture \\ West Pomeranian University of Technology in Szczecin, Papieża Pawła VI/3A, 71-459 Szczecin, Poland \\ e-mail: piotr.zurawik@zut.edu.pl
}

Received: 24.07.2012

\section{Abstract}

In the years 2007-2008, experiments were conducted with four cultivars of garden pansy grown in pots, in media prepared as mixtures of wet shrimp waste (BioHydroHumus) and sphagnum peat at the following volumetric ratios: $2 \%$ BioHydroHumus $+98 \%$ sphagnum peat, $5 \%$ BioHydroHumus $+95 \%$ sphagnum peat, $10 \%$ BioHydroHumus $+90 \%$ sphagnum peat. The Osmocote Exact 5-6 M (15:8:10:3MgO + microelements) fertilizer at the rates of 2.5 and $5.0 \mathrm{~g} \times \mathrm{dm}^{-3}$ was added to each medium. Sphagnum peat with addition of $5.0 \mathrm{~g} \times \mathrm{dm}^{-3}$ Osmocote Exact 5-6 M was used as control medium.

It was found that BioHydroHumus can be a source of macroelements in the cultivation of garden pansy. It is characterized by alkaline reaction and high total soluble salts. BioHydroHumus used as a component of media affects the quality of cultivated plants. The best results were obtained when BioHydroHumus was used at the rates of 2 and $5 \%$, even if the rate of fertilizer were twice smaller than in control medium. At full flowering, plants grown in medium containing 5\% BioHydroHumus were the most branched. Garden pansies cultivated in medium containing $10 \%$ BioHydroHumus were characterized by a smaller number of leaves. Plants grown in media with addition of 2 and $5 \%$ BioHydroHumus flowered more abundantly in comparison with garden pansies cultivated in medium containing 10\% BioHydroHumus, regardless of the rate of fertilizer. However, an ambiguous influence of BioHydroHumus on height and diameter of garden pansy cultivars was found.

Key words: Viola $x$ wittrockiana, BioHydroHumus, shrimp waste, growth, flowering

\section{INTRODUCTION}

\section{BioHydroHumus}

in cultivation of garden pansy

Garden pansy has been one of the most popular bedding and pot plants for many years [1]. Cultivars of garden pansy grown recently, e.g. from the groups Butterfly and Carrera, can be cultivated also as annuals $[2,3]$.

According to many authors [4-6], post-production shrimp waste is characterized by alkaline reaction and is a source of macro- and microelements for plants. A few experiments have been carried out to examine if shrimp waste can be recommended as organic fertilizer for cultivation of vegetables - broccoli and sweet pepper [7-9]. The positive results of those experiments show that shrimp waste can be used in the cultivation of vegetables. However, there is a lack of information concerning the possible use of shrimp waste in the cultivation of ornamental plants.

The aim of the present experiments was to examine selected chemical properties of BioHydroHumus and to evaluate if wet shrimp waste can be recommended for cultivation of garden pansy as a medium component.

\section{MATERIALS AND METHODS}

From January to July in the years 2007-2008, two pot experiments were carried out in the Department of Ornamental Plants in Szczecin. Four cultivars of garden pansy - small-flowered Butterfly Purple and Yellow as well as large-flowered Carrera Yellow with Blotch, Cats Yellow and Fancy Blue with Blotch, were the experimental material.

In the first decade of January, seeds of garden pansy were sown in boxes filled with growing medium prepared using sphagnum peat deacidified with

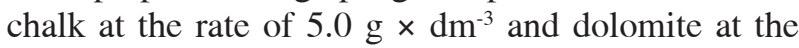
rate of $5.0 \mathrm{~g} \times \mathrm{dm}^{-3}$ to $\mathrm{pH} 5.8$ in 2007 and to 6.8 in 2008. The growing medium was supplemented with the multicomponent fertilizer Osmocote Exact 5-6 M 
$(15: 8: 10: 3 \mathrm{MgO}+$ microelements) at the rate of $2.5 \mathrm{~g}$ $\times \mathrm{dm}^{-3}$. The boxes were covered with perforated foil and put on cultivation tables in a greenhouse with air temperature of $16-18^{\circ} \mathrm{C}$.

Wet shrimp waste - BioHydroHumus - was prepared from post-production shrimp waste and distilled water at a volumetric ratio $1: 3$, mixed and homogenized by means of the device Homogenizer TYPE-324. The homogenate was filtered through a sieve with square holes with a side length of $1 \mathrm{~mm}$. In $2007 \mathrm{BioHy}-$ droHumus was obtained in the Department of Packaging and Polymers of the Agricultural University of Szczecin and in 2008 the filtrate was prepared in the Department of Ornamental Plants of the Agricultural University of Szczecin, currently the West Pomeranian University of Technology in Szczecin.

Before planting seedlings, samples of BioHydroHumus were collected and the following determinations were made: $\mathrm{pH}$ (in $\mathrm{H}_{2} \mathrm{O}$ ); total soluble salts; available forms of $\mathrm{N}^{-\mathrm{NO}_{3}}$ (by the ionometric method); $\mathrm{P}$ (by the colorimetric method); K, Ca (by the flame photometry method); $\mathrm{Mg}$ (by the method of atomic spectrometry absorption); $\mathrm{Cl}$ (by the ionometric method). The results of the analyses for each year of the experiments are included in Table 1.

A week before the planned date of planting seedlings (in the second decade of February), four media were prepared. Sphagnum peat deacidified with chalk at the rate of $5.0 \mathrm{~g} \times \mathrm{dm}^{-3}$ and dolomite at the rate of $5.0 \mathrm{~g} \times \mathrm{dm}^{-3}$ with addition of Osmocote Exact 5-6 M $(15: 8: 10: 3 \mathrm{MgO}+$ microelements) at the rate of $5.0 \mathrm{~g}$ $\times \mathrm{dm}^{-3}$ was used as control medium. The other media were prepared by mixing BioHydroHumus and sphagnum peat at a volumetric ratio of $2 \%$ BioHydroHumus $+98 \%$ sphagnum peat deacidified with chalk at the rate of $4.0 \mathrm{~g} \times \mathrm{dm}^{-3}$ and dolomite at the rate of $4.0 \mathrm{~g}$ $\times \mathrm{dm}^{-3} ; 5 \%$ BioHydroHumus $+95 \%$ sphagnum peat

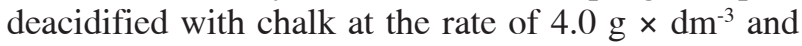

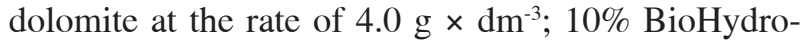
Humus $+90 \%$ sphagnum peat deacidified with chalk at the rate of $3.0 \mathrm{~g} \times \mathrm{dm}^{-3}$ and dolomite at the rate of $3.0 \mathrm{~g} \times \mathrm{dm}^{-3}$. Selected chemical properties and content of nutrients were determined in prepared media. The results of the chemical analyses are included in Table 2. The slow-release fertilizer Osmocote Exact 5-6 M was added to media containing BioHydroHumus at the rates of 2.5 and $5.0 \mathrm{~g} \times \mathrm{dm}^{-3}$.

At the stage of two fully expanded leaves (in the third decade of February), seedlings were transplanted to $0.4 \mathrm{dm}^{3}$ pots. The pots were placed on field patches covered with black foil in an unheated plastic tunnel. In the first decade of May, plants were taken from the plastic tunnel and put on the cultivation tables without protection covers. During the whole vegetation period, no additional fertilization was used.
At the beginning of flowering (in the second decade of May) and at full flowering (in the second decade of June), measurements were made of the vegetative traits of plants. Plant height, plant diameter and total number of leaves were measured. From the beginning of flowering, all flowers were counted and picked at weekly intervals to determine the total number of flowers per plant.

Each year after the end of the experiment (in the first decade of July), collective samples of media were obtained from the pots and their chemical analyses were carried out. $\mathrm{pH}$, total soluble salts and content of nutrients were determined using the same methods as at the beginning of the experiments. The results of the chemical analyses are included in Table 3.

28 experimental treatments included medium (7) and cultivar (4). Each treatment consisted of 16 plants, divided into 4 replications. The experiments were set up as a completely randomized design. The results were statistically analyzed by two-way analysis of variance and the differences between means were verified using Tukey's test at the significance level of $\alpha=0.05$.

\section{RESULTS}

In the first year of the research, the content of potassium, calcium and magnesium in $\mathrm{BioHydroHu}-$ mus was very high. The content of chlorine was too high and harmful to garden pansy. However, in the following year of the experiments a higher content of nitrogen and phosphorus as well as a lower content of potassium, calcium, magnesium and chlorine, and over three times lower total soluble salts were found in BioHydroHumus (Table 1). The results of chemical analyses of the mixtures containing sphagnum peat and BioHydroHumus conducted before planting seedlings showed that in both years of the experiment those media were characterized by slightly acidic reaction, very low to medium total soluble salts and a low content of nitrogen (Table 2). The content of phosphorus and potassium was higher in the first year of the research than in the second one.

On the basis of chemical analysis of media made after the end of the experiment (Table 3), it was found that in 2007 both media containing 2\% BioHydroHumus and $98 \%$ sphagnum peat and also medium containing 5\% BioHydroHumus, 95\% sphagnum peat and Osmocote Exact 5-6 M at the rate of $2.5 \mathrm{~g} \times \mathrm{dm}^{-3}$ were characterized by a low content of nitrogen and phosphorus, a higher content of potassium, slightly acidic to neutral reaction and very low total soluble salts. Medium containing 5\% BioHydroHumus, 95\% sphagnum peat and Osmocote Exact 5-6 $\mathrm{M}$ at the rate of $5.0 \mathrm{~g} \times \mathrm{dm}^{-3}$ and also both media containing $10 \%$ BioHydroHumus and 90\% sphagnum peat in 2007 were 
characterized by a higher content of nitrogen, phosphorus and potassium in comparison with the other media evaluated and also by low to medium total soluble salts and by acidic or slightly acidic reaction. In the second year of the research, all media evaluated were more abundant in nitrogen, phosphorus and potassium than in 2007. Medium containing 2\% BioHydroHumus, 98\% sphagnum peat and Osmocote Exact 5-6 $\mathrm{M}$ at the rate of $2.5 \mathrm{~g} \times \mathrm{dm}^{-3}$ was characterized by the lowest content of phosphorus and potassium, however the mixture of 10\% BioHydroHumus and 90\% sphagnum peat with addition of Osmocote Exact 5-6 $\mathrm{M}$ at the rate of $5.0 \mathrm{~g} \times \mathrm{dm}^{-3}$ was characterized by the highest content of those macroelements. The mixtures of BioHydroHumus with sphagnum peat were characterized by acidic or slightly acidic reaction and medium or high total soluble salts. Medium containing $10 \%$ BioHydroHumus and $90 \%$ sphagnum peat with addition of Osmocote Exact 5-6 M at the rate of $5.0 \mathrm{~g}$ $\times \mathrm{dm}^{-3}$ was an exception, because it was characterized by excessive total soluble salts.

In the present experiment, on the basis of statistical analysis of the results it was found that in the first year (at the beginning of flowering and at full flowering) medium significantly affected total height of plants (Tab. 4, Tab. 5). However, no effect of medium on plant height was found in 2008. At the beginning of flowering in the first year of the experiments, plants grown in both media containing $2 \%$ BioHydroHumus and $98 \%$ sphagnum peat were the highest regardless of cultivar. At full flowering in 2007, plants grown in medium containing 2\% BioHydroHumus, $98 \%$ sphagnum peat and Osmocote Exact 5-6 M at the rate of $5.0 \mathrm{~g} \times$ $\mathrm{dm}^{-3}$ were the highest. In 2007 garden pansies of the cultivars Butterfly Purple and Yellow as well as Carrera Yellow with Blotch were higher than plants of the cultivars Cats Yellow and Fancy Blue with Blotch, regardless of medium. However, in 2008 garden pansies of the cultivars Butterfly Purple and Yellow, Carrera Yellow with Blotch and Cats Yellow were higher than plants of the cultivar Fancy Blue with Blotch. In the first year of the research at the beginning of flowering and at full flowering and in the second year of the research at full flowering, the cultivars reacted differently to media evaluated.

It was found that garden pansies differed in plant diameter depending on medium in both years of the experiment at the beginning of flowering and at full flowering (Table 6, Table 7). Regardless of cultivar, at both dates of measurement in 2007 pansies grown in medium containing $10 \%$ BioHydroHumus, $90 \%$ sphagnum peat and $5.0 \mathrm{~g} \times \mathrm{dm}^{-3}$ Osmocote Exact 5-6 M were characterized by the greatest diameter as opposed to plant height. In the second year of the research at the beginning of flowering and at full flowering, plants with the greatest diameter were obtained in medium containing 5\% BioHydroHumus, 95\% sphagnum peat and $5.0 \mathrm{~g} \times \mathrm{dm}^{-3}$ Osmocote Exact 5-6 M. However, garden pansies grown in the mixture of $2 \%$ BioHydroHumus and $98 \%$ sphagnum peat with addition of $2.5 \mathrm{~g}$ $\times \mathrm{dm}^{-3}$ Osmocote Exact 5-6 M had the smallest diameter. In 2007 at the beginning of flowering, garden pansies of the cultivar Carrera Yellow with Blotch were characterized by a greater diameter only in comparison with plants of the cultivar Cats Yellow. No such relationship was found at full flowering. However, in the year 2008, at the beginning of flowering garden pansies of cultivar Carrera Yellow with Blotch were characterized by greater diameter in comparison with cultivars Butterfly Purple and Yellow, Fancy Blue with Blotch and Cats Yellow. At full flowering, garden pansies of cultivars Butterfly Purple and Yellow and Carrera Yellow with Blotch were characterized by a greater diameter than the other cultivars evaluated. An interaction between cultivar and medium was found only in the first year of the research.

In both years of the experiment at the beginning of flowering and at full flowering, medium was found to have a significant effect on number of leaves of garden pansy (Table 8, Table 9). At the beginning of flowering in the first year of the research, plants grown in medium containing 5\% BioHydroHumus, 95\% sphagnum peat and $5.0 \mathrm{~g} \times \mathrm{dm}^{-3}$ Osmocote Exact 5-6 M were characterized by the greatest number of leaves, regardless of cultivar. At full flowering in 2007, plants grown in both media containing 5\% BioHydroHumus and 95\% sphagnum peat were characterized by the highest number of leaves, but control plants had the smallest number of leaves. At the beginning of flowering in 2008, control plants cultivated in both media containing $2 \%$ BioHydroHumus and $98 \%$ sphagnum peat and pansies grown in the mixture of 5\% BioHydroHumus and 95\% sphagnum peat with addition of $2.5 \mathrm{~g} \times \mathrm{dm}^{-3}$ Osmocote Exact 5-6 $\mathrm{M}$ were characterized by the highest number of leaves. They had on average $51 \%$ more leaves than plants grown in the mixture of $10 \%$ BioHydroHumus, $90 \%$ sphagnum peat and $5.0 \mathrm{~g} \times \mathrm{dm}^{-3}$ Osmocote Exact $5-6 \mathrm{M}$. At full flowering in 2008, control plants, garden pansies cultivated in the mixture of $2 \%$ BioHydroHumus and $98 \%$ sphagnum peat with addition of $5.0 \mathrm{~g} \times$ $\mathrm{dm}^{-3}$ Osmocote Exact 5-6 M, and also plants grown in both media containing 5\% BioHydroHumus and 95\% sphagnum peat were characterized by the greatest number of leaves. In both years of the research at the beginning of flowering and at full flowering, the number of leaves depended on cultivar traits and garden pansies of the cultivar Butterfly Purple and Yellow were characterized by the greatest number of leaves. In the years 2007 and 2008, a different reaction of the garden pansy cultivars to media was also found. 
Table 1

Selected chemical properties of BioHydroHumus - years 2007 and 2008

\begin{tabular}{ccccccccc}
\hline \multirow{2}{*}{ Year } & $\mathrm{pH}\left(\mathrm{H}_{2} \mathrm{O}\right)$ & $\begin{array}{c}\text { Total soluble salts } \\
{\left[\mathrm{g} \mathrm{NaCl} \times \mathrm{dm}^{-3}\right]}\end{array}$ & $\mathrm{N}-\mathrm{NO}_{3}$ & $\mathrm{P}$ & $\mathrm{K}$ & $\mathrm{Ca}$ & $\mathrm{Mg}$ & $\mathrm{Cl}$ \\
\cline { 4 - 8 } & 7.7 & 22.2 & 147 & 284 & 3010 & 6045 & 654 & 20300 \\
2007 & 7.6 & 6.6 & 286 & 440 & 220 & 1210 & 275 & 1640 \\
2008 & & & & &
\end{tabular}

Table 2

Selected chemical properties in media before planting seedlings - years 2007 and 2008

\begin{tabular}{|c|c|c|c|c|c|c|c|c|c|}
\hline \multirow{2}{*}{ Year } & \multirow{2}{*}{ Medium } & \multirow{2}{*}{$\mathrm{pH}\left(\mathrm{H}_{2} \mathrm{O}\right)$} & \multirow{2}{*}{ 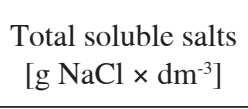 } & \multicolumn{6}{|c|}{ Content $\left[\mathrm{mg} \cdot \mathrm{dm}^{-3}\right]$} \\
\hline & & & & $\mathrm{N}-\mathrm{NO}_{3}$ & $\mathrm{P}$ & $\mathrm{K}$ & $\mathrm{Ca}$ & $\mathrm{Mg}$ & $\mathrm{Cl}$ \\
\hline \multirow{4}{*}{2007} & $1 *$ & 5.8 & 0.32 & 10 & 23 & 28 & 1797 & 218 & 20 \\
\hline & 2 & 6.2 & 0.54 & 10 & 131 & 36 & 1320 & 200 & 92 \\
\hline & 3 & 5.9 & 0.78 & 13 & 63 & 63 & 1200 & 195 & 242 \\
\hline & 4 & 5.8 & 1.40 & 11 & 63 & 103 & 825 & 182 & 478 \\
\hline \multirow{4}{*}{2008} & 1 & 6.8 & 0.34 & 13 & 14 & 25 & 2879 & 300 & 19 \\
\hline & 2 & 6.2 & 0.46 & 16 & 9 & 34 & 1726 & 179 & 111 \\
\hline & 3 & 6.1 & 0.89 & 16 & 18 & 62 & 1328 & 133 & 217 \\
\hline & 4 & 6.2 & 0.67 & 12 & 11 & 87 & 1171 & 109 & 323 \\
\hline
\end{tabular}

*Explanations:

1 - sphagnum peat deacidified with chalk and dolomite - control;

$2-2 \%$ BioHydroHumus $+98 \%$ sphagnum peat deacidified with chalk and dolomite;

$3-5 \%$ BioHydroHumus $+95 \%$ sphagnum peat deacidified with chalk and dolomite;

$4-10 \%$ BioHydroHumus $+90 \%$ sphagnum peat deacidified with chalk and dolomite.

Table 3

Selected chemical properties and the content of nutrients in media after the end of the experiment - years 2007 and 2008

\begin{tabular}{|c|c|c|c|c|c|c|c|c|c|}
\hline \multirow{2}{*}{ Year } & \multirow{2}{*}{ Medium } & \multirow{2}{*}{$\mathrm{pH}\left(\mathrm{H}_{2} \mathrm{O}\right)$} & \multirow{2}{*}{ 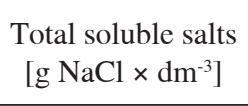 } & \multicolumn{6}{|c|}{ Content $\left[\mathrm{mg} \times \mathrm{dm}^{-3}\right]$} \\
\hline & & & & $\mathrm{N}-\mathrm{NO}_{3}$ & $\mathrm{P}$ & $\mathrm{K}$ & $\mathrm{Ca}$ & $\mathrm{Mg}$ & $\mathrm{Cl}$ \\
\hline \multirow{7}{*}{2007} & $\mathrm{I}^{* *}$ & 6.8 & 0.23 & 5 & 17 & 84 & 1808 & 426 & 34 \\
\hline & II & 6.6 & 0.21 & 6 & 17 & 106 & 1679 & 426 & 24 \\
\hline & III & 6.5 & 0.29 & 7 & 24 & 193 & 1729 & 458 & 33 \\
\hline & IV & 6.4 & 0.28 & 9 & 23 & 180 & 1544 & 403 & 29 \\
\hline & $\mathrm{V}$ & 6.0 & 0.60 & 109 & 46 & 273 & 1776 & 399 & 40 \\
\hline & VI & 5.9 & 0.61 & 86 & 33 & 214 & 1541 & 382 & 42 \\
\hline & VII & 5.0 & 1.32 & 353 & 99 & 332 & 1452 & 357 & 52 \\
\hline \multirow{7}{*}{2008} & I & 6.2 & 1.97 & 459 & 149 & 407 & 2736 & 530 & 137 \\
\hline & II & 6.1 & 1.42 & 175 & 76 & 195 & 1744 & 377 & 78 \\
\hline & III & 5.6 & 2.30 & 385 & 141 & 389 & 1823 & 423 & 84 \\
\hline & IV & 5.9 & 1.68 & 139 & 78 & 221 & 1517 & 390 & 135 \\
\hline & V & 5.8 & 2.97 & 248 & 153 & 401 & 1566 & 449 & 117 \\
\hline & VI & 5.6 & 2.25 & 252 & 86 & 277 & 1733 & 351 & 282 \\
\hline & VII & 5.7 & 4.35 & 430 & 259 & 622 & 1678 & 476 & 325 \\
\hline
\end{tabular}

**Explanations:

I - sphagnum peat deacidified with chalk and dolomite $+5.0 \mathrm{~g} \times \mathrm{dm}^{-3}$ Osmocote Exact 5-6 M- control;

II $-2 \%$ BioHydroHumus $+98 \%$ sphagnum peat deacidified with chalk and dolomite $+2.5 \mathrm{~g} \times \mathrm{dm}^{-3}$ Osmocote Exact 5-6 M;

III $-2 \%$ BioHydroHumus $+98 \%$ sphagnum peat deacidified with chalk and dolomite $+5.0 \mathrm{~g} \times \mathrm{dm}^{-3}$ Osmocote Exact 5-6 M;

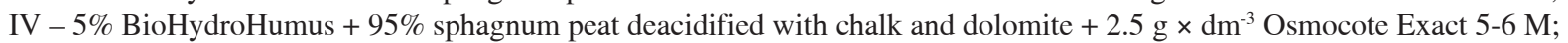

$\mathrm{V}-5 \%$ BioHydroHumus $+95 \%$ sphagnum peat deacidified with chalk and dolomite $+5.0 \mathrm{~g} \times \mathrm{dm}^{-3}$ Osmocote Exact 5-6 M;

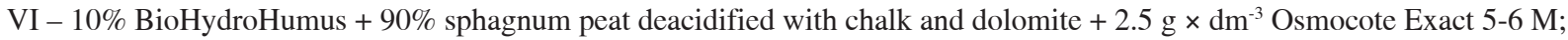

VII $-10 \%$ BioHydroHumus $+90 \%$ sphagnum peat deacidified with chalk and dolomite $+5.0 \mathrm{~g} \times \mathrm{dm}^{-3}$ Osmocote Exact 5-6 M 
Table 4

Total height $[\mathrm{cm}]$ of garden pansy depending on medium and cultivar - beginning of flowering, years 2007 and 2008

\begin{tabular}{|c|c|c|c|c|c|c|}
\hline \multirow[b]{2}{*}{ Year } & \multirow[b]{2}{*}{ Medium (A) } & \multicolumn{4}{|c|}{ Cultivar (B) } & \multirow[b]{2}{*}{$\operatorname{Mean}(\mathrm{A})$} \\
\hline & & $\begin{array}{c}\text { Butterfly Purple } \\
\text { and Yellow }\end{array}$ & $\begin{array}{c}\text { Carrera Yellow } \\
\text { with Blotch }\end{array}$ & Cats Yellow & $\begin{array}{l}\text { Fancy Blue } \\
\text { with Blotch }\end{array}$ & \\
\hline \multirow{9}{*}{2007} & $\mathrm{I}^{* *}$ & 8.9 & 11.6 & 11.3 & 12.4 & 11.1 \\
\hline & II & 12.0 & 13.4 & 11.8 & 12.2 & 12.4 \\
\hline & III & 13.7 & 13.0 & 12.1 & 12.2 & 12.8 \\
\hline & IV & 11.7 & 11.3 & 10.0 & 10.0 & 10.8 \\
\hline & $\mathrm{V}$ & 12.6 & 11.8 & 10.5 & 10.0 & 11.2 \\
\hline & VI & 10.8 & 10.0 & 6.9 & 6.7 & 8.6 \\
\hline & VII & 9.0 & 9.3 & 6.6 & 7.5 & 8.1 \\
\hline & Mean (B) & 11.2 & 11.5 & 9.9 & 10.1 & \\
\hline & $\mathrm{LSD}_{0.05}$ & & $\mathrm{~A}-1.16 \quad \mathrm{~B}-0.76$ & $6 \quad \mathrm{~B}(\mathrm{~A})-2.01$ & $\mathrm{~A}(\mathrm{~B})-2.32$ & \\
\hline \multirow{9}{*}{2008} & I & 8.6 & 9.2 & 10.7 & 9.2 & 9.4 \\
\hline & II & 9.3 & 8.7 & 7.9 & 7.3 & 8.3 \\
\hline & III & 10.2 & 11.4 & 8.9 & 7.6 & 9.5 \\
\hline & IV & 10.0 & 10.8 & 8.9 & 7.4 & 9.3 \\
\hline & $\mathrm{V}$ & 8.6 & 10.0 & 9.0 & 8.0 & 8.9 \\
\hline & VI & 9.5 & 10.2 & 9.9 & 7.3 & 9.2 \\
\hline & VII & 9.1 & 9.4 & 8.9 & 8.4 & 9.0 \\
\hline & Mean (B) & 9.3 & 10.0 & 9.2 & 7.9 & \\
\hline & $\mathrm{LSD}_{0.05}$ & \multicolumn{4}{|c|}{$\mathrm{A}-\mathrm{n} . \mathrm{s} . * * * \quad \mathrm{~B}-1.12 \quad \mathrm{~A} \times \mathrm{B}-\mathrm{n} . \mathrm{s}}$. & \\
\hline
\end{tabular}

**Explanations as in Table 3

$* * *$ n.s. - not significant difference

Table 5

Total height $[\mathrm{cm}]$ of garden pansy depending on medium and cultivar - full flowering, years 2007 and 2008

\begin{tabular}{|c|c|c|c|c|c|c|c|}
\hline \multirow[b]{2}{*}{ Year } & \multirow[b]{2}{*}{ Medium (A) } & \multicolumn{5}{|c|}{ Cultivar (B) } & \multirow[b]{2}{*}{ Mean (A } \\
\hline & & $\begin{array}{c}\text { Butterfly Purple } \\
\text { and Yellow }\end{array}$ & $\begin{array}{r}\text { Carrera Yello } \\
\text { with Blotch } \\
\end{array}$ & $\begin{array}{l}\text { ow } \\
\mathrm{h}\end{array}$ & ats Yellow & $\begin{array}{l}\text { Fancy Blue } \\
\text { with Blotch }\end{array}$ & \\
\hline \multirow{9}{*}{2007} & I & 11.1 & 12.3 & & 12.4 & 13.7 & 12.4 \\
\hline & II & 12.8 & 15.2 & & 14.0 & 14.9 & 14.2 \\
\hline & III & 17.5 & 14.2 & & 14.6 & 13.7 & 15.0 \\
\hline & IV & 13.9 & 14.6 & & 10.8 & 11.3 & 12.7 \\
\hline & $\mathrm{V}$ & 16.5 & 15.2 & & 11.5 & 11.2 & 13.6 \\
\hline & VI & 12.4 & 12.8 & & 10.5 & 10.7 & 11.6 \\
\hline & VII & 13.4 & 13.8 & & 9.1 & 8.8 & 11.3 \\
\hline & Mean (B) & 13.9 & 14.0 & & 11.8 & 12.0 & \\
\hline & $\mathrm{LSD}_{0.05}$ & & $\mathrm{~A}-2.32$ & B -1.52 & $\mathrm{~B}(\mathrm{~A})-4.03$ & $\mathrm{~A}(\mathrm{~B})-4.65$ & \\
\hline \multirow{9}{*}{2008} & I & 9.7 & 9.4 & & 12.8 & 9.6 & 10.4 \\
\hline & II & 10.9 & 9.5 & & 8.7 & 8.0 & 9.3 \\
\hline & III & 10.6 & 11.6 & & 9.7 & 8.8 & 10.2 \\
\hline & IV & 10.2 & 11.8 & & 9.5 & 7.7 & 9.8 \\
\hline & $\mathrm{V}$ & 8.8 & 11.7 & & 9.5 & 8.5 & 9.6 \\
\hline & VI & 10.0 & 10.4 & & 11.4 & 8.9 & 10.2 \\
\hline & VII & 9.3 & 9.7 & & 9.1 & 9.1 & 9.3 \\
\hline & Mean (B) & 9.9 & 10.6 & & 10.1 & 8.7 & \\
\hline & $\mathrm{LSD}_{0.05}$ & & A-n.s.; r.n. & B -1.09 & $9 \quad \mathrm{~B}(\mathrm{~A})-2.89$ & $\mathrm{~A}(\mathrm{~B})-3.33$ & \\
\hline
\end{tabular}

Explanations as in Table 3 
Table 6

Diameter [cm] of garden pansy depending on medium and cultivar - beginning of flowering, years 2007 and 2008

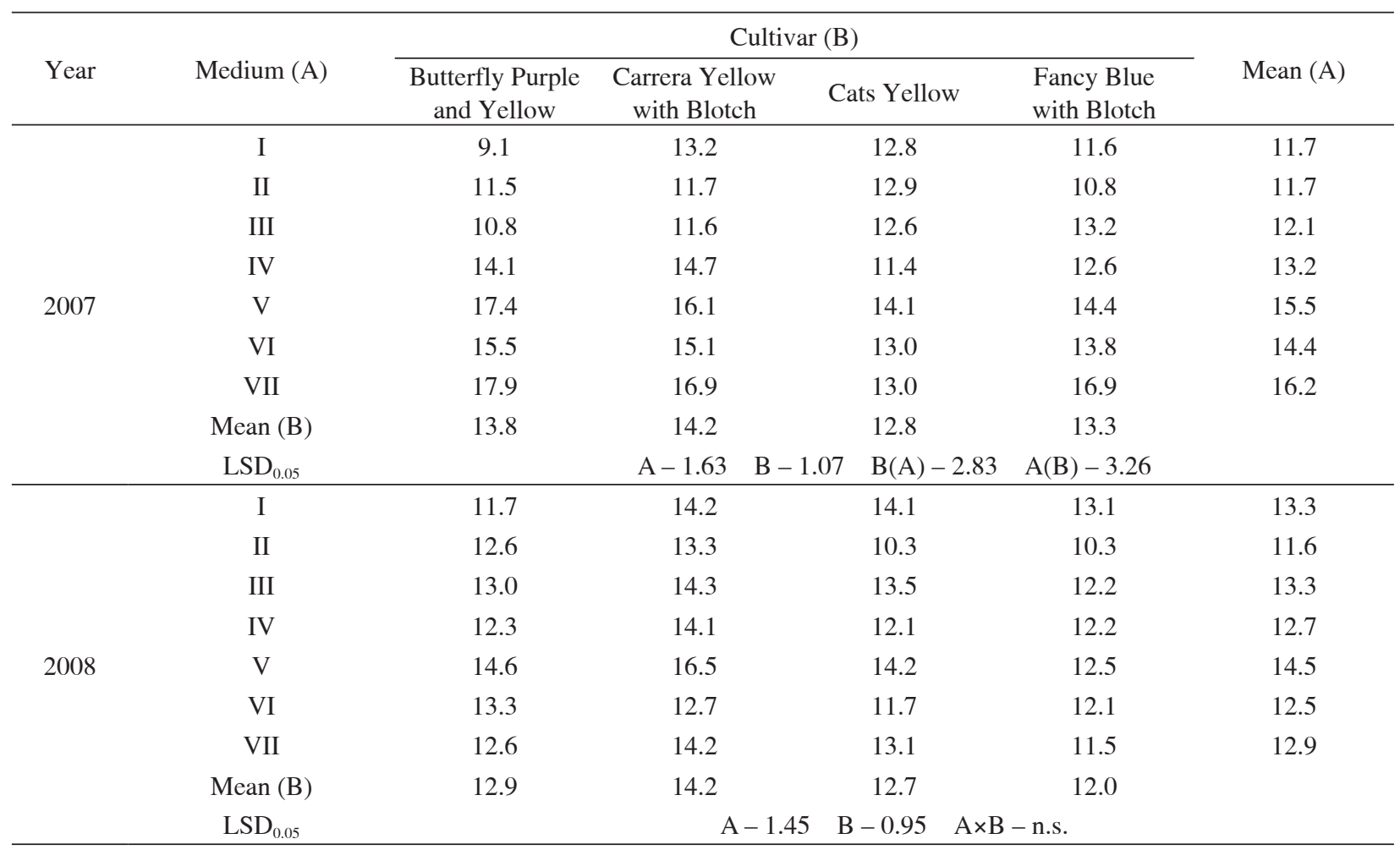

Explanations as in Table 3

Table 7

Diameter [cm] of garden pansy depending on medium and cultivar - full flowering, years 2007 and 2008

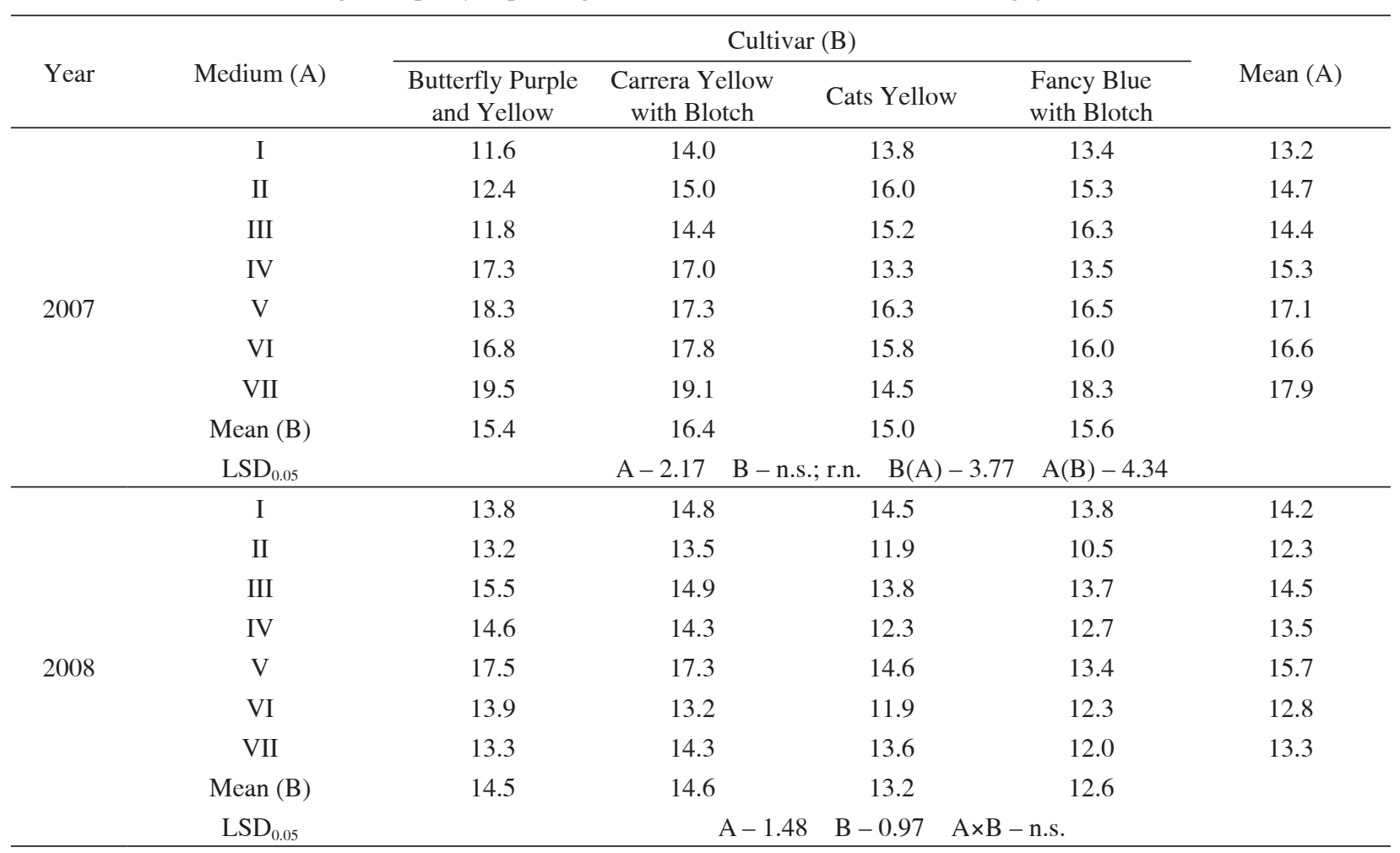

Explanations as in Table 3 
Table 8

Number of leaves [pcs.] of garden pansy depending on medium and cultivar - beginning of flowering, years 2007 and 2008

\begin{tabular}{|c|c|c|c|c|c|c|c|}
\hline \multirow[b]{2}{*}{ Year } & \multirow[b]{2}{*}{ Medium (A) } & \multicolumn{5}{|c|}{ Cultivar (B) } & \multirow[b]{2}{*}{ Mean (A } \\
\hline & & $\begin{array}{c}\text { Butterfly Purple } \\
\text { and Yellow }\end{array}$ & $\begin{array}{r}\text { Carrera Yell } \\
\text { with Blotcl }\end{array}$ & & Cats Yellow & $\begin{array}{l}\text { Fancy Blue } \\
\text { with Blotch }\end{array}$ & \\
\hline \multirow{9}{*}{2007} & I & 10.8 & 12.0 & & 11.3 & 10.2 & 11.1 \\
\hline & II & 18.5 & 12.0 & & 11.9 & 11.1 & 13.4 \\
\hline & III & 26.9 & 14.4 & & 16.4 & 13.3 & 17.8 \\
\hline & IV & 32.5 & 24.3 & & 23.0 & 27.0 & 26.7 \\
\hline & V & 32.9 & 25.3 & & 25.4 & 31.6 & 28.8 \\
\hline & VI & 34.2 & 25.1 & & 18.3 & 17.8 & 23.9 \\
\hline & VII & 24.3 & 10.7 & & 7.3 & 9.1 & 12.9 \\
\hline & Mean (B) & 25.7 & 17.7 & & 16.2 & 17.2 & \\
\hline & $\mathrm{LSD}_{0.05}$ & & $\mathrm{~A}-3.00$ & B -1.97 & $7 \quad \mathrm{~B}(\mathrm{~A})-5.20$ & $\mathrm{~A}(\mathrm{~B})-5.99$ & \\
\hline \multirow{9}{*}{2008} & I & 30.3 & 20.8 & & 21.1 & 23.4 & 23.9 \\
\hline & II & 30.9 & 22.0 & & 17.8 & 16.8 & 21.9 \\
\hline & III & 30.0 & 19.1 & & 17.5 & 21.2 & 22.0 \\
\hline & IV & 33.4 & 18.2 & & 16.0 & 16.9 & 21.1 \\
\hline & $\mathrm{V}$ & 26.4 & 14.3 & & 15.2 & 15.9 & 18.0 \\
\hline & VI & 18.8 & 12.7 & & 14.0 & 16.5 & 15.5 \\
\hline & VII & 19.5 & 13.8 & & 10.5 & 15.0 & 14.7 \\
\hline & Mean (B) & 27.0 & 17.3 & & 16.0 & 18.0 & \\
\hline & $\mathrm{LSD}_{0.05}$ & & $A-2.97$ & B - 1.95 & $5 \quad \mathrm{~B}(\mathrm{~A})-5.15$ & $\mathrm{~A}(\mathrm{~B})-5.94$ & \\
\hline
\end{tabular}

Explanations as in Table 3

Table 9

Number of leaves [pcs.] of garden pansy depending on medium and cultivar - full flowering, years 2007 and 2008

\begin{tabular}{|c|c|c|c|c|c|c|c|}
\hline \multirow[b]{2}{*}{ Year } & \multirow[b]{2}{*}{ Medium (A) } & \multicolumn{5}{|c|}{ Cultivar (B) } & \multirow[b]{2}{*}{ Mean (A) } \\
\hline & & $\begin{array}{c}\text { Butterfly Purple } \\
\text { and Yellow }\end{array}$ & $\begin{array}{r}\text { Carrera Yell } \\
\text { with Blotc }\end{array}$ & & Cats Yellow & $\begin{array}{l}\text { Fancy Blue } \\
\text { with Blotch }\end{array}$ & \\
\hline \multirow{9}{*}{2007} & I & 18.5 & 22.3 & & 15.5 & 11.3 & 16.9 \\
\hline & II & 19.5 & 19.7 & & 17.8 & 14.5 & 17.9 \\
\hline & III & 27.9 & 21.0 & & 17.3 & 14.5 & 20.2 \\
\hline & IV & 33.5 & 26.0 & & 25.8 & 27.8 & 28.3 \\
\hline & $\mathrm{V}$ & 35.5 & 27.3 & & 29.0 & 32.5 & 31.1 \\
\hline & VI & 34.8 & 25.8 & & 18.8 & 20.0 & 24.9 \\
\hline & VII & 25.0 & 19.5 & & 15.0 & 14.5 & 18.5 \\
\hline & Mean (B) & 27.8 & 23.1 & & 19.9 & 19.3 & \\
\hline & $\mathrm{LSD}_{0.05}$ & & $\mathrm{~A}-2.90$ & $\mathrm{~B}-1.90$ & $\mathrm{~B}(\mathrm{~A})-5.04$ & $\mathrm{~A}(\mathrm{~B})-5.81$ & \\
\hline \multirow{9}{*}{2008} & I & 36.0 & 21.5 & & 22.6 & 25.8 & 26.5 \\
\hline & II & 37.0 & 25.4 & & 21.1 & 18.0 & 25.4 \\
\hline & III & 36.2 & 22.9 & & 21.1 & 30.5 & 27.7 \\
\hline & IV & 38.1 & 22.5 & & 20.1 & 22.4 & 25.8 \\
\hline & $\mathrm{V}$ & 37.5 & 20.5 & & 25.5 & 32.5 & 29.0 \\
\hline & VI & 26.2 & 21.3 & & 16.4 & 21.3 & 21.3 \\
\hline & VII & 21.8 & 17.5 & & 23.0 & 20.1 & 20.6 \\
\hline & Mean (B) & 33.3 & 21.7 & & 21.4 & 24.4 & \\
\hline & $\mathrm{LSD}_{0.05}$ & & $\mathrm{~A}-4.30$ & B -2.82 & $2 \quad \mathrm{~B}(\mathrm{~A})-7.46$ & $\mathrm{~A}(\mathrm{~B})-8.59$ & \\
\hline
\end{tabular}

Explanations as in Table 3 
In both years of the research, garden pansies differed in total number of flowers, depending on medium (Table 10). Regardless of cultivar, in 2007 plants grown in medium containing $2 \%$ BioHydroHumus, $98 \%$ sphagnum peat and $5.0 \mathrm{~g} \times \mathrm{dm}^{-3}$ Osmocote Exact $5-6 \mathrm{M}$ were characterized by the greatest number of flowers. In the second year of the experiments, control plants and those grown in medium containing 5\% BioHydroHumus and $95 \%$ sphagnum peat, with addition of $5.0 \mathrm{~g} \times \mathrm{dm}^{-3}$ Osmocote Exact 5-6 M flowered most abundantly. In 2007 and 2008, regardless of cultivar, plants grown in media containing $10 \%$ BioHydroHumus and $90 \%$ sphagnum peat were characterized by the smallest number of flowers. In 2007 plants of the cultivar Butterfly Purple and Yellow were characterized by the greatest number of flowers and pansies of the cultivars Carrera Yellow with Blotch and Cats Yellow had the least number of flowers. However, in 2008 plants of the cultivar Butterfly Purple and Yellow were characterized by the greater number of flowers in comparison with the other cultivars evaluated. In both years of the research, an interaction between medium and cultivar was found.

Table 10

Total number of flowers [pcs.] of garden pansy depending on medium and cultivar - years 2007 and 2008

\begin{tabular}{|c|c|c|c|c|c|c|c|}
\hline \multirow[b]{2}{*}{ Year } & \multirow[b]{2}{*}{ Medium (A) } & \multicolumn{5}{|c|}{ Cultivar (B) } & \multirow[b]{2}{*}{ Mean (A) } \\
\hline & & $\begin{array}{c}\text { Butterfly Purple } \\
\text { and Yellow }\end{array}$ & $\begin{array}{r}\text { Carrera Yel } \\
\text { with Blotc } \\
\end{array}$ & $\begin{array}{l}\text { low } \\
\text { ch }\end{array}$ & Cats Yellow & $\begin{array}{l}\text { Fancy Blue } \\
\text { with Blotch }\end{array}$ & \\
\hline \multirow{9}{*}{2007} & I & 164.4 & 45.3 & & 39.8 & 63.1 & 78.2 \\
\hline & II & 173.2 & 43.9 & & 39.7 & 73.4 & 82.6 \\
\hline & III & 207.7 & 47.8 & & 46.8 & 74.2 & 94.1 \\
\hline & IV & 164.2 & 40.1 & & 38.2 & 67.3 & 77.5 \\
\hline & $\mathrm{V}$ & 190.2 & 39.5 & & 31.8 & 67.0 & 82.1 \\
\hline & VI & 170.8 & 28.6 & & 26.8 & 58.0 & 71.1 \\
\hline & VII & 162.8 & 37.4 & & 28.6 & 61.9 & 72.7 \\
\hline & Mean (B) & 176.2 & 40.4 & & 36.0 & 66.4 & \\
\hline & $\mathrm{LSD}_{0.05}$ & & $\mathrm{~A}-8.14$ & B - 5.34 & $\mathrm{~B}(\mathrm{~A})-14.12$ & $\mathrm{~A}(\mathrm{~B})-16.28$ & \\
\hline \multirow{9}{*}{2008} & I & 47.2 & 17.8 & & 12.7 & 14.4 & 23.0 \\
\hline & II & 37.4 & 11.1 & & 12.0 & 13.5 & 18.5 \\
\hline & III & 47.8 & 15.8 & & 10.2 & 15.1 & 22.2 \\
\hline & IV & 44.9 & 16.9 & & 12.5 & 15.5 & 22.5 \\
\hline & V & 55.8 & 14.9 & & 14.8 & 17.9 & 25.9 \\
\hline & VI & 33.6 & 8.5 & & 7.7 & 9.6 & 14.9 \\
\hline & VII & 29.0 & 7.2 & & 6.0 & 6.2 & 12.1 \\
\hline & Mean (B) & 42.2 & 13.2 & & 10.8 & 13.2 & \\
\hline & $\mathrm{LSD}_{0.05}$ & & $\mathrm{~A}-4.24$ & B -2.78 & $8 \quad \mathrm{~B}(\mathrm{~A})-7.36$ & $\mathrm{~A}(\mathrm{~B})-8.48$ & \\
\hline
\end{tabular}

Explanations as in Table 3

\section{DISCUSSION}

The obtained results of chemical analyses of BioHydroHumus used in the experiments are in agreement with the results obtained by $[5,10,11]$ which show that shrimp waste is an important source of phosphorus, potassium and sodium. The large differences in the content of potassium, calcium and chlorine in the successive years of the research and over three times higher total soluble salts in 2007 than in 2008 could have been caused by a different origin of shrimps and a different chemical composition of shrimp carapace. The authors et al. $[5,6,12]$ are of the opinion that shrimp waste contains, besides macroelements, also a little amount of microelements, sometimes even silver.
On the basis of the ranges determined by [13], we can say that total soluble salts in BioHydroHumus were very high and harmful to plants in both years of the research.

The low content of nutrients in both media containing 2\% BioHydroHumus and $98 \%$ sphagnum peat and also in the mixture of 5\% BioHydroHumus and $95 \%$ sphagnum peat with addition of $2.5{\mathrm{~g} \times \mathrm{dm}^{-3}}^{-3}$ Osmocote Exact 5-6 M after the end of the first year of the experiments probably resulted from their intensive intake and use by plants.

There is a lack of information in Polish and foreign literature concerning the optimal content of basic nutrients in media for garden pansy. In the present experiment and in the experiments conducted by [2], 
it was found that the content of macronutrients in all media containing BioHydroHumus was insufficient for plants. That was why those media must have been supplemented with fertilizer before their use. Similar relationships were found in the experiments conducted by $[7,8]$ where media used in cultivation of vegetables were supplemented with shrimp waste as organic fertilizer but also with mineral fertilizer.

In both years of the experiment, the height of plants at the beginning of flowering and at full flowering was affected by cultivar traits. Those results are partially consistent with the results of the experiments conducted by $[14,15]$ where the evaluated garden pansy cultivars from the groups Carrera and Colossus reacted differently to media containing composts of different composition.

On the basis of the obtained results, it was found that garden pansies grown in media containing 2 and $5 \%$ BioHydroHumus were well formed and flowered abundantly, regardless of the rate of mineral fertilizer added to medium. These results are in agreement with the observations of [8]. They showed that in the cultivation of sweet pepper mineral fertilization is also important, besides shrimp waste used as organic fertilizer, and the use of slow-release fertilizers from the Osmocote group has positive effects.

According to [7-9], the highest yield of sweet pepper and broccoli of best quality can be obtained when also mineral fertilizer is added at a low or medium rate to media besides shrimp waste as a source of nutrients for plants. High rates of mineral fertilizers have an effect on increasing total soluble salts in media and this can cause the deterioration of the quality of plants and their deformations. In our own experiments, the slower growth of plants cultivated in the mixtures containing $10 \%$ BioHydroHumus, especially in the second year of the research, could have resulted from high total soluble salts in media (Table 3). Limited growth of plants as the effect of higher total soluble salts in medium has also been confirmed by the results of experiments with many ornamental plants, e.g. cultivars of Rhododendron [16] or Madagascar periwinkle [17].

According to $[5,6,12]$, shrimp waste often contains components harmful to plants, i.e. heavy metals (lead, cadmium). It is possible that in the present experiments the higher content of heavy metals in media containing 10\% BioHydroHumus compared to the mixtures containing 2 and 5\% wet shrimp waste also had an effect on limited plant growth and development.

It is also possible that mixtures of wet shrimp waste and sphagnum peat could be recommended for cultivation of plants with higher nutritional requirements than garden pansy. However, this problem needs to be examined in detail.

\section{CONCLUSIONS}

1. Wet shrimp waste (BioHydroHumus) is characterized by alkaline reaction, high total soluble salts and is a source of macroelements for plants.

2. Media containing 2\% BioHydroHumus and $98 \%$ sphagnum peat and also $5 \%$ BioHydroHumus and 95\% sphagnum peat can be recommended for garden pansy production. Plants grown in these media are compact, well-formed and flower abundantly, even if a twice smaller rate of slow-release fertilizer than in control medium is used.

3. Media containing $10 \%$ BioHydroHumus and $90 \%$ sphagnum peat are characterized by high total soluble salts; plants grown in these media are of poorer quality than control plants.

4. The cultivar Butterfly Purple and Yellow is characterized by the greatest decorative value among the cultivars evaluated, has the most leaves and flowers most abundantly.

\section{Acknowledgements}

Research supported by the Ministry of Science and Higher Education of Poland as part of the statutory activities of the Laboratory of Ornamental Plants in the Department of Horticulture, West Pomeranian University of Technology in Szczecin.

\section{Author's contributions}

The following declarations about authors' contributions to the research have been made: designing the experiments: PŻ, MP; field research: PŻ, MP; data analyses: PŻ, MP; writing the manuscript: PZ̈, MP.

\section{REFERENCES}

1. Kelly R.O., Deng Z., Harbaugh B.K. Evaluation of viola cultivars as bedding plants and establishment of the best-of-class. Hort Tech. 2006; 16 (1): 167-171.

2. S t a r te k L. Wpływ podłoża i nawożenia bratków ogrodowych (Viola $\times$ wittrockiana Gams.) na ich dynamikę wzrostu, kwitnienie oraz trwałość walorów dekoracyjnych. / Effects of the substrate and fertilization on growth dynamics, flowering and permanence of decorative value of garden pansies Viola x wittrockiana Gams. Zesz. Prob. Post. Nauk Rol. 2002; 484: 629-636. (in Polish)

3. Startek L., Janicka D., Dobrowolska A., Plac e k M. Wpływ rodzaju podłoża na dynamikę wschodów i czas trwania fazy wegetatywnej bratka ogrodowego z grup Carrera i Butterfly. / The effects of medium on emergence dynamics and the length of vegetative stage of pansy belonging to Carrera and Butterfly Groups. Zesz. Prob. Post. Nauk Rol. 2006; 510: 601-608. (in Polish)

4. Evers D.J., Carroll D.J. Preservation of crab and shrimp waste as silage for cattle. Anim. Feed Sci. Tech. 
1996; 59(4): 233-244. http://dx.doi.org/10.1016/0377-8401 (95)00908-6.

5. Ibrahim H.M., Salama M.F., El-Banna H.A. Shrimp's waste: chemical composition, nutritional value and utilization. Nahrung 1999; 43(6): 418-423. http://dx.doi.org/ 10.1002/(SICI)1521-3803(19991201)43:6<418::AID-FOOD418>3.3.CO;2-Y.

6. Adeniyi A.A., Oduguwab O.O., Asunumeh O.C., Ikekhua Y.O., Fabiyi A.O. Levels of total petroleum hydrocarbons (TPH) and heavy metals in shrimp waste meal supplemented broiler feeds and droppings. Pakistan J. Sci. Ind. R. 2004; 47(1): 1-4.

7. Dufault R.J., Hopkins S., Sandifer P. Potential of shrimp biosolids from aquaculture lagoons as a soil amendment for bell pepper production. Proc. Nat. Pepper Conf. 1996: 96-97.

8. Dufault R.J., Korkmaz A., Ward B. Potential of biosolids from shrimp aquaculture as a fertilizer for broccoli production. Compost Sci. Util. 2001; 9(2): 107-114.

9. Dufault R.J., Korkmaz A. Potential of biosolids from shrimp aquaculture as a fertilizer in bell pepper production. Compost Sci. Util. 2000; 8(4): 310-319.

10. Seymour T.A., Li S.J., Morrissey M.T. Characterization of a natural antioxidant from shrimp shell waste. J. Agr. Food Chem. 1996; 44(3): 682-685. http://dx.doi. org/10.1021/jf950597f.

11. Rao M.S, Stevens W.F. Fermentation of shrimp biowaste under different salt concentrations with amylolytic and non-amylolytic Lactobacillus strains for chitin production. Food Technol. Biotechnol. 2006; 44(1): 83-87.

12. Chui V.W.D., Mok K.W., Ng C.Y., Luong B.P., Ma K.K. Removal and recovery of copper (II), chromium (III), and nickel (II) from solutions using crude shrimp chitin packed in small columns. Environ. Int. 1996; 22(4): 463-468. http://dx.doi.org/10.1016/0160-4120(96)00034-7.

13. Strojny Z., Nawożenie roślin ozdobnych pod osłonami. / Fertilization of ornamental plants under covers. Skierniewice: Centrum Ogrodnicze; 1993. (in Polish)

14. Placek M., Janicka D., Piechocki R. Zastosowanie kompostów w uprawie bratka ogrodowego. Część I. Wzrost roślin. / Using of composts in cultivation of pansy. Part I. Growth of plants. Folia Univ. Agric. Stetin. Agric. Aliment. Pisc. Zootech. 2008a; 262: 93-100. (in Polish)

15. Placek M., Janicka D., Piechocki R. Zastosowanie kompostów w uprawie bratka ogrodowego. Część II. Rozwój i jakość roślin. / Using of composts in cultivation of pansy. Part II. Development and quality of plants. Folia
Univ. Agric. Stetin. Agric. Aliment. Pisc. Zootech. 2008b; 262: 101-108. (in Polish)

16. Cabrera R.I. Growth, quality and nutrient responses of Azalea hybrids to salinity. Acta Hort. 2003; 609: 241-245.

17. Jaleel C.A., Sankar B., Sridharan R., Panne ers elvam R. Soil salinity alters growth, chlorophyll content, and secondary metabolite accumulation in Catharanthus roseus. Turk. J. Biol. 2008; 32: 79-93.

\section{Wpływ biohydrohumusu na wzrost i rozwój bratka ogrodowego (Viola $x$ wittrockiana Gams.)}

\section{Streszczenie}

W latach 2007-2008 przeprowadzono doświadczenia $\mathrm{z}$ czterema odmianami bratka ogrodowego uprawianymi w doniczkach, w podłożach przygotowanych jako mieszaniny mokrego odpadu krewetkowego (BioHydroHumus) i torfu wysokiego w proporcjach objętościowych: $2 \%$ BioHydroHumusu $+98 \%$ torfu wysokiego, $5 \%$ BioHydroHumusu $+95 \%$ torfu wysokiego, $10 \%$ BioHydroHumusu $+90 \%$ torfu wysokiego. Do każdego podłoża dodano nawóz Osmocote Exact 5-6 M (15:8:10:3MgO + mikroelementy) w dawkach 2,5 i 5,0 $\mathrm{g} \times \mathrm{dm}^{-3}$. Torf wysoki z dodatkiem $5,0 \mathrm{~g} \times \mathrm{dm}^{-3}$ Osmocote Exact 5-6 M stanowił podłoże kontrolne.

Stwierdzono, że BioHydroHumus może stanowić źródło makroelementów w uprawie bratka ogrodowego. Charakteryzuje się odczynem zasadowym i wysokim stężeniem soli. BioHydroHumus użyty jako składnik podłoży ma wpływ na jakość uprawianych roślin. Najlepsze wyniki uzyskano, gdy BioHydroHumus użyto w dawkach 2 i 5\%, nawet jeśli dawka nawozu była dwukrotnie mniejsza niż w podłożu kontrolnym. W pełni kwitnienia rośliny uprawiane w podłożu zawierającym 5\% BioHydroHumusu były najbardziej rozłożyste. Bratki rosnące w podłożu zawierającym 10\% BioHydroHumusu odznaczały się mniejszą liczbą liści. Niezależnie od dawki zastosowanego nawozu, rośliny uprawiane w podłożach $\mathrm{z}$ dodatkiem 2 i 5\% BioHydroHumusu kwitły obficiej, w porównaniu z bratkami rosnącymi w podłożu zawierającym $10 \%$ BioHydroHumusu. Nie wykazano natomiast jednoznacznego wpływu BioHydroHumusu na wysokość i średnicę roślin odmian bratka ogrodowego.

Handling Editor: Elżbieta Weryszko-Chmielewska

This is an Open Access digital version of the article distributed under the terms of the Creative Commons Attribution 3.0 License (creativecommons.org/licenses/by/3.0/), which permits redistribution, commercial and non-commercial, provided that the article is properly cited.

(C)The Author(s) 2013 Published by Polish Botanical Society 